\title{
FURTHER ADDITIONS TO THE GRASS MOTH (LEPIDOPTERA: CRAMBIDAE) FAUNA OF CROATIA
}

\author{
TONI KOREN \\ Association Hyla, Lipovac I 7, HR-10000 Zagreb, Croatia \\ (e-mail: toni.koren@hhdhyla.hr)
}

Koren, T.: Further additions to the grass moth (Lepidoptera: Crambidae) fauna of Croatia. Nat. Croat., Vol. 30, No. 1, 243-250, 2021, Zagreb.

Six species of grass moths (Crambidae) were recorded for the first time in Croatia. Chilo luteellus, Chilo pulverosellus and Thopeutis galleriellus were recorded in the Neretva River delta, showing the importance and great biodiversity of this Ramsar site, one of the largest Mediterranean wetlands. Euchromius rayatellus was recorded near Žmanska Lakes, a wetland area on Island Dugi otok. Two montane species were also recorded for the first time in the country, Catoptria combinella from Mt. Risnjak and Udea cyanalis from four montane areas across Croatia. The known range of occurrence of each of the recorded species in the Balkan peninsula is accordingly expanded. The discovery of these species shows the need for additional Microlepidoptera surveys in the country. With these records, the fauna of Crambidae of Croatia has now risen to 218 species. This number is however probably far from final and new surveys are expected to reveal additional species for the fauna of Croatia.

Keywords: Microlepidoptera, diversity, Neretva River delta, montane fauna

Koren, T.: Novi dodatci fauni moljaca trava (Lepidoptera: Crambidae) Hrvatske. Nat. Croat., Vol. 30, No. 1, 243-250, 2021, Zagreb.

Šest vrsta moljaca trava (Crambidae) zabilježeno je prvi put u Hrvatskoj. Chilo luteellus, Chilo pulverosellus i Thopeutis galleriellus zabilježeni su u delti rijeke Neretve, pokazujući važnost i veliku biološku raznolikost ovog Ramsarskog područja i jedne od najvećih mediteranskih močvara. Euchromius rayatellus zabilježen je u blizini Zmanskih jezera, močvarnog područja na Dugom otoku. Dvije planinske vrste također su prvi put zabilježene za Hrvatsku, Catoptria combinella s područja Nacionalnog parka Risnjak te Udea cyanalis iz četiri planinska područja diljem zemlje. Nalaz svake od spomenutih vrsta proširuje njihov poznati areal na Balkanskom poluotoku. Otkriće ovih vrsta ukazuje na potrebu za dodatnim istraživanjima Microlepidoptera u zemlji. S ovim nalazima, fauna porodice Crambidae u Hrvatskoj sada sadrži 218 vrsta. Taj je broj, međutim, vjerojatno daleko od konačnog, a očekuje se da će se novim istraživanjima bilježiti i dodatne vrste za faunu Hrvatske.

Ključne riječi: Microlepidoptera, raznolikost, Delta Neretve, planinska fauna

\section{INTRODUCTION}

Grass moths (Crambidae) belong to one of the most well-known microlepidoptera families in Europe; there are excellent identification keys for most of the genera (LERAUT, 2012; Slamka, 2006, 2008, 2013) as well as detailed literature overviews even for eastern European countries (e.g. Plant \& JAKŠIĆ, 2018). In Croatia, this is one of few microlepidoptera families that have recently been dealt with in detail (PLANT \& JAKŠIĆ, 2018; Gumhalter, 2019a, b). Nevertheless, most of the data available for this family in Croatia are based on literature records and limited museum collections, while new and more comprehensive faunistic data remain scarce (e.g. Koren, 2018, 2020; GumHALTER \& Kučinić, 2020). Almost every new detailed survey of the country reveals 
important data about the diversity of this family, and with the creation of the most recent checklist, it is now much easier to put the new information into a meaningful perspective. Accordingly, with the survey of previously unresearched areas of the country, additional species are being included in the national list on a frequent basis (e.g. Koren, 2020; Koren \& Kulijer, 2020). So far, 210 Crambidae species were known from Croatia (Plant \& Jakšić, 2018; Gumhalter, 2019a, b; Koren, 2020; Koren \& Kulijer, 2020). The goal of this paper is to present records of six previously unrecorded Crambidae for the fauna of Croatia.

\section{MATERIALS AND METHODS}

Microlepidoptera material has been collected in Croatia by the author for the last ten years. Crambidae were collected along with other Lepidoptera families using pyramidal UV light traps. Usually, five traps were in operation for about $4 \mathrm{~h}$ after dusk at each locality. All the data for the visited localities are provided in the next chapter for each recorded species. The collected specimens were set, identified and stored in the private collection of the author. For the identification of species, SLAMkA (2006, 2008, 2013) and LERAut (2012) were used and for all specimens the correct identification was confirmed also by the examination of male or female genital armature.

\section{RESULTS AND DISCUSSION}

During this survey, six species were recorded in Croatia for the first time. For each species, examined specimens are discussed and notes given concerning their distribution and status.

Thopeutis galleriellus (Ragonot in Staudiger, 1892) (Fig. 1, Fig. 2a)

Material examined: Croatia, Neretva River delta, Rogotin, $500 \mathrm{~m}$ south of the settlement, karstic hill surrounded by reeds and channels, $43.040050^{\circ} \mathrm{N}, 17.477583^{\circ} \mathrm{E} ; 6$ m; 8.VII.2016, 1 f, leg. TK.

Notes: The species has so far been recorded in Spain, France, Romania, Montenegro, Greece, Bulgaria, Ukraine and Russia as well as northern Africa, the Caucasus, Asia Minor, Iran, India and Sri Lanka (Slamka, 2008; Plant \& Jakšić, 2018). On the web portal Lepiforum, there is also a record from Albania (LEPIFORUM, 2020), a country in which the species has not been reported before (PLANT \& JAKŠı́c, 2018). This, along with the record from the Neretva River delta, expands the known distribution in the Balkan peninsula. As is the case with similar "brown" wetland Crambidae, sexual dimorphism is also present in this species. The wingspan in males is 20-26 $\mathrm{mm}$ and between 27-35 $\mathrm{mm}$ in females (SlamkA, 2008). Females are similar to larger Calamotropha species, e.g. C. paludella, but differ in their more oblong forewing edges as well as in the white line running in the apical part of the forewing. This species inhabits forest-steppe biotopes along rivers (ANIKIN et al., 2003). Only a single female specimen was collected, again in the Neretva River delta but the scarcity of reports might be a consequence of the similarity with Calamotropha species, which are extremely common in the recorded locality. 


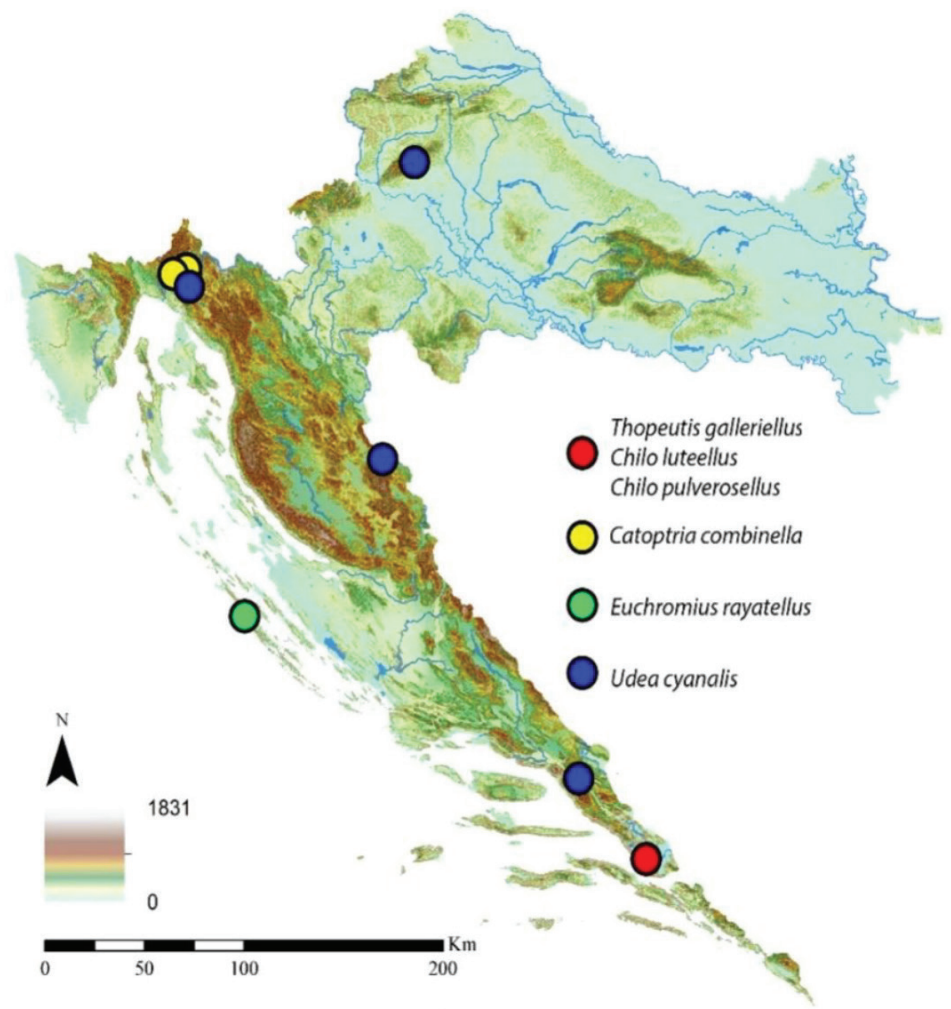

Fig. 1. Distribution of six newly recorded Crambidae species in Croatia.

Chilo luteellus (Motschulsky, 1866) (Fig. 1, Fig. 2b)

Material examined: Croatia, Neretva River delta, Rogotin, $500 \mathrm{~m}$ south of the settlement, karstic hill surrounded by reeds and channels, $43.040050^{\circ} \mathrm{N}, 17.477583^{\circ} \mathrm{E}$, 6 m, 28.VIII.2015, 2 m, leg. TK; Neretva River, Opuzen, Crepina village, reed banks and agricultural land, $43.007307^{\circ} \mathrm{N}, 17.525403^{\circ} \mathrm{E}, 1 \mathrm{~m}$; 26.VI.2016, 4m, 2f, leg. TK; Croatia, Neretva River delta, mouth of Neretva river near the small chapel, calcareous hill surrounded by reed channels, $43.024857^{\circ} \mathrm{N}, 17.462471^{\circ} \mathrm{E}, 6 . \mathrm{VIII} .2012,1$ ex., leg. TK.

Notes: The distribution of this species includes Spain, France, Italy, Bulgaria, Romania, Greece Russia, Caucasus and Uralsk region (SlamkA, 2008). The records from Croatia contribute to their general distribution in the Balkans and fill the gap between Greece and Italy. Fresh specimens of Ch. luteellus can be easily separated from the larger Ch. phragmitellus by the shiny longitudinal dark scales scattered on their forewing (Slamka, 2008). This is visible on almost all Ch. luteellus specimens from Neretva River delta (Fig. 2b).

Chilo pulverosellus Ragonot, 1895 (Fig. 1, Fig. 2c)

Material examined: Croatia, Neretva River, road between Metković and Vid, marshy vegetation surrounding reed channels around river Norin, $43.073019^{\circ} \mathrm{N}$, 17.638136 E; 0 m; 18.VIII.2020, 1f, 2m, leg. TK. 
Notes: Chilo pulverosellus is similar to the other members of the genus Chilo, but the labial palpi are shorter and forewing venation is often dark-scaled (SLAMKA, 2008). According to Asselbergs (2006) Ch. pulverosellus has labial palps of 2.5 x eye-diameter; the vertex is conical without a pinnacle and the forewings have a blackish discal and median spot. In Ch. luteellus the size of labial palps is 4 x eye-diameter in the male and $5 \mathrm{x}$ in the female; the vertex is conical with a pinnacle and the forewings are without blackish spots (Asselbergs, 2006). In fresh Chilo sp. specimens, wing colorations are also very different in these two species. According to SLAMKA (2008) the species inhabits open habitats, including agricultural landscapes. Larvae have been found on Zea mays (SlamkA, 2008). From the material collected in the Neretva River delta during the moth survey three specimens belonged to this species. This is a new species for Croatia, and a rather significant one as it both greatly expands the known range of the species and also bridges the gap between Italy and Eastern Europe. It is distributed in scattered localities across Spain, France, Italy, Bulgaria, Crimea, Asia Minor, Syria, Palestine, Transcaucasia and Trans-Caspian (Asselbergs, 2006; Slamka, 2008).



Fig. 2. a) Thopeutis galleriellus from Rogotin, Neretva; b) Chilo luteellus from Rogotin, Neretva; c) Chilo pulverosellus from reed channels around the river Norin. 


\section{Euchromius rayatellus (Amsel, 1949) (Fig. 1, Fig. 3a)}

Material examined: Croatia, Dugi Otok, Žman, Žmanska jezera, wetlands around the big lake, $43.948625^{\circ} \mathrm{N}, 15.099270^{\circ} \mathrm{E}, 55 \mathrm{~m}, 1$. VII.2014, 1m, 1f, leg. TK.

Notes: This species is distributed in Spain, Italy, Montenegro, Bulgaria, Crimea, Greece, Crete, Russia, Asia Minor, Jordan, Iran, Iraq down to Afghanistan (SLAmkA, 2008). The species has not been recorded in Croatia so far (Plant \& Jakšıć, 2008, Gumhalter, 2019b) but it was expected as it is known from Montenegro (Schouten, 1992). The record from Croatia is the northernmost record for this species in the Balkan peninsula.

\section{Udea cyanalis (La Harpe, 1855) (Fig. 1, Fig. 3b)}

Material examined: National Park Risnjak, Guslica, edge of Fagus forest and montane grasslands, $45.45295^{\circ} \mathrm{N}, 14.5718^{\circ} \mathrm{E} ; 1190 \mathrm{~m} ; 8$. VII.2020, 3 ex., leg. TK; NP Risnjak, Kupa River valley, meadows closest to river spring, $45.49591^{\circ} \mathrm{N}, 14.697971^{\circ} \mathrm{E} ; 651 \mathrm{~m}$, 20.VI.2019, 1 ex., leg. TK; Nature Park Medvednica, Vejalnica meadows, southern part, $45.917063^{\circ} \mathrm{N}, 16.075008^{\circ} \mathrm{E} ; 458$ m, 26.VI.2015, 1 M, leg. TK; Mt. Lička Plješevica, Bijeli potoci, Poljane, montane meadows and edge of Fagus forest, $44,679579^{\circ} \mathrm{N}$, $15.845102^{\circ}$ E; 1040 m, 2.VII.2018, 3 ex., leg. TK; Mt. Biokovo, Silnji gozd, Fagus forest surrounded by grasslands, $43.325556^{\circ} \mathrm{N}, 17.056667^{\circ} \mathrm{E} ; 1430 \mathrm{~m}, 28 . V I .2018,4$ ex., leg TK; 28.VII.2018, 5 ex., leg. TK.

Notes: This is a predominantly alpine species, known also from Spain, France, Germany, Slovenia, Bosnia \& Herzegovina, Romania (Slamka, 2013; Plant \& Jakšić, 2019). Previously it was recorded from four mountain areas: Mt. Medvednica, NP Risnjak, Mt. Lička Plješevica and Mt. Biokovo. According to Slamka (2013) this species is very local and rare but these new records from Croatia indicate a rather wide distribution in the country, covering most of the montane area. A single specimen was collected on Mt. Medvednica at a low altitude of $458 \mathrm{~m}$ a.s.l., but otherwise the species has been observed at altitudes above $1000 \mathrm{~m}$. At Mt. Biokovo no fewer than ten specimens were observed and five of them were collected. The species has not been reported from the recent survey of Pyraloidea of Mt. Biokovo (Gumhalter \& KuČInIĆ, 2020). The records from Croatia expand the known range of this species in the Balkans.

\section{Catoptria combinella (Denis \& Schiffermüller, 1775) (Fig. 1, Fig. 3c)}

Material examined: NP Risnjak, Guslica, edge of Fagus forest and montane grasslands, 45,45295 ${ }^{\circ}$ N, 14,5718 E; 1190 m; 21.VII.2020, 3 ex., leg. TK; NP Risnjak, Snježnik, montane meadows around the peak; $45,438365^{\circ} \mathrm{N}, 14,584635^{\circ} \mathrm{E} ; 1253 \mathrm{~m} ; 19$. VII.2019, $1 \mathrm{ex}$.

Notes: This species is predominantly distributed in the Alps, while single records exist outside this mountain chain, from the Carpathians (SLAMKA, 2008). The closest records to the populations in Croatia are from Slovenia, where the species has been recorded many times (see Plant \& JAKšić, 2008 detailed references). The record from Croatia expands the known area of distribution outside the Alps to the alpine mountains of Guslica and Snježnik located within Risnjak National Park, but this was expected as similar distribution patterns were observed in other montane Crambidae species (Koren, 2020). The most similar species present in Croatia (Gumhalter, 2009b) 




Fig. 3. a) Euchromius rayatellus from Žmanska lakes, Dugi otok, b) Udea cyanalis from Mt. Biokovo, c) Catoptria combinella from Guslica peak.

is Catoptria petrificella (Hübner, 1796). The male and female genital structures of $C$. petrificella and C. combinella are very similar, and the separation of the species through the examination of genitalia is difficult and normally not possible (SLAMKA, 2008). The specimens collected in Croatia all display the typical coloration and markings of $C$. combinella (SLAMKa, 2008). In C. combinella the whitish streak is complete and is not cut by dark line as it is in C. petrificiella (SLAMKa, 2008).

\section{DISCUSSION}

In total, 310 species of Crambidae have been recorded in the Balkan peninsula (PLANT \& JAKŠIĆ, 2018). As a result of the present survey, and taking into account two more species published in another article in this issue (GUMHALTER, 2021), the Crambidae family in Croatia now comprises 218 species (Gumhalter, 2019b; Koren, 2020; Koren \& KUlJer, 2020). Still, this number is probably far from final as most of the area of the country still needs to be explored. 
The records of these three new species to the Croatian fauna, along with recent records of Friedlanderia cicatricella (Koren, 2020) and Euclasta splendidalis (Koren, 2012; Gumhalter et al., 2018) emphasizes the importance of this wetland area for the conservation of Crambidae of the country. One needs to take into consideration that this is however the only wetland area that has been surveyed in detail for the Crambidae fauna (Koren, in prep.). It is probable that T. galleriellus, as well as some of the other mentioned species, will be recorded in other coastal wetlands in Croatia in future surveys. Such places are few and far between, but exist along the shoreline (e.g. Nin saltworks, Ston saltworks, Vransko lake, Prološko blato etc.) and even on the Adriatic islands (Veliki Brijun saltworks, Pag saltworks, Kolansko blato on Pag etc.). Saltworks are important, and for some species unique habitats, and a survey of them would be beneficial for the increase in the knowledge of the fauna of such habitats. In neighboring Slovenia Sečovlje saltworks has proved to be an extremely important habitat for Lepidoptera diversity (GOMBOC \& TORKAR, 2020).

With two montane species, Udea cyanalis and Catoptria spatullelus, recorded during this survey, two additional species, Udea alpinalis, Crambus ericella and the first exact record of the third, Catoptria pyramidellus, have been recorded in the country just recently (KOREN, 2020). Accordingly, it is probable that the mountains in the country harbor many additional species, and additional surveys are needed in those areas. Even species new to science seem to inhabit these regions (e.g. Slamka \& Plant, 2016).

Aside from the general faunistic inventories, which are a nice start for insect groups, future efforts should be aimed atexploring the conservation status of Crambidae and other Heterocera families in Croatia and the region. This is a standard practice in other, better surveyed areas (e.g. Nuss et al., 2011; Allen et al., 2016). In addition, DNA barcoding should be used to facilitate species identification and indicate or even solve possible taxonomical problems within this group. Barcoding has already proved to be avaluable tool in solving certain taxonomic problems within the Crambidae (e.g. YANG et al., 2012) and should be applied on a much large scale.

\section{ACKNOWLEDGMENTS}

I am grateful to the Public Institution for the Management of Protected Natural Areas of the Dubrovnik-Neretva region for financing the moth surveys in the Neretva River delta, Croatia. My thanks also go to František Slamka for confirming the identification of Catoptria combinella. I am also grateful to the two anonymous referees who greatly improved the quality of this manuscript.

Received December 15, 2020

\section{REFERENCES}

Allen, D., O’Donnell, M., Nelson, B., Tyner, A., Bond, K.G.M., Bryant, T., Crory, A., Mellon, C., O’Boyle, J., O’Donnell, E., Rolston, T., Sheppard, R., Strickland, P., Fitzpatrick, U. \& Regan, E., 2016: Ireland Red List No. 9: Macro-moths (Lepidoptera). National Parks and Wildlife Service, Department of Arts, Heritage and the Gaeltacht, Dublin, Ireland.

Anikin, V. V., Sachkov, S. A., Zolotuhin, V. V. \& Ustiuzhanin, P. Y., 2003: Fauna Lepidopterologica Volgo-Uralensis.' 150 years later: changes and additions. Part 7. Pyrales et Pterophores (Insecta, Lepidoptera). Atalanta 34(1/2), 223-250. 
Asselbergs, J., 2006: Chilo pulverosellus Ragonot, 1895, new to the Spanish fauna (Lepidoptera: Crambidae). SHILAP Revista de Lepidopterología 34, 155-157.

Gomboc, S. \& Torkar, G., 2010: Biodiverziteta metuljev (Lepidoptera), kobilic (Orthoptera), dvoživk (Amphibia) in plazilcev (Reptilia) Krajinskega parka Sečoveljske soline: rezultati proučevanj, 36-40.

Gumhalter, D., Kučinić, M., Vajdić, M., Perović, F., Pelić Fixa, D. \& Lukač, G., 2018: New records of the crambid moth Euclasta splendidalis (Herrich-Schäffer, [1848]) (Lepidoptera: Crambidae) in Croatia with notes on Pyraloidea fauna from the Neretva Valley. Natura Croatica 27, 225-232.

Gumhalter, D., 2019a: First checklist of pyraloid moths (Lepidoptera: Pyraloidea) in Croatia. Zootaxa $4604,59-102$.

Gumhalter, D., 2019b: A revised checklist of pyraloid moths (Lepidoptera: Pyraloidea) in Croatia. Natura Croatica 28, 271-288.

Gumhalter, D., 2021: Psorosa mediterranella (Amsel, 1954) (Lepidoptera: Pyralidae, Phycitinae) - a new species for the Croatian pyraloid moth fauna, with an updated checklist. Nat. Croat. 30 (1), 37-52.

Gumhalter, D. \& Kučinić, M., 2020: Contribution to the knowledge of the Croatian Pyraloidea fauna. Species reported from Biokovo Natural Park (Insecta: Lepidoptera). SHILAP Revista de Lepidopterología 1-19.

Koren, T., 2012: The western most record of Euclasta splendidalis (Herrich-Schäffer, 1884) (Lepidoptera: Crambidae) in Europe. Polish Journal of Entomology 81, 331-334.

Koren, T., 2018: Diversity of moths (Lepidoptera: Heterocera) in the surroundings of the Bednja River, Varaždin County, Northern Croatia. Natura Croatica 18, 111-141.

Koren, T., 2020: Three montane grass moths (Lepidoptera: Crambidae) new to the fauna of Croatia. Acta Entomologica Serbica25, 29-34.

Koren, T. \& Kuljuer, D., 2020: Additions to the Crambidae (Insecta: Lepidoptera) fauna of Croatia and Bosnia \& Herzegovina. Acta entomologica Slovenica 28(2), 141-147.

LEPIFORUM E.V. [ed.], 2020: Thopeutis galleriellus (Ragnot in Staudiger, 1892).

LEPIFORUM E.V. [ed.] (2008-2020): Bestimmungshilfe für die in Europa nachgewiesenen Schmetterlingsarten. Visited on November 3rd, 2020. http://www.lepiforum.de/lepiwiki.pl?Thopeutis_ Galleriellus

Leraut, P., 2012: Moths of Europe, Volume 3: Zygaenids, Pyralids 1 and Brachodids. Verrieres-le Buisson. NAP Editions, 599 pp.

Nuss, M., 2011: Rote Liste und Gesamtartenliste der Zünslerfalter (Lepidoptera: Pyraloidea) Deutschlands. - In: Binot-Hafke, M.; Balzer, S.; Becker, N.; Gruttke, H.; Haupt, H.; Hofbauer, N.; Ludwig, G.; Matzke-Hajek, G. \& Strauch, M. (Red.): Rote Liste gefährdeter Tiere, Pflanzen und Pilze Deutschlands. Band 3: Wirbellose Tiere (Teil 1). - Münster (Landwirtschaftsverlag). Naturschutz und Biologische Vielfalt 70(3), 327-370.

Plant, C.W. \& Jakšić, P., 2018: A provisional checklist and bibliography of the Pyraloidea of the Balkan Peninsula (Lepidoptera: Pyralidae \& Crambidae). Atalanta 49, 219-263.

Schouten, R. T. A., 1992: Revision of the Genera Euchromius Guenée and Miyakea Marumo (Lepidoptera: Crambidae: Crambinae). Tijdschriftvoor Entomologie 135(1), 191-274.

Slamka, F.,2006: Pyraloidea of Europe (Lepidoptera) 1. Pyralinae, Galleriinae, Epipaschiinae, Cathariinae \& Odontiinae. Bratislava: František Slamka, 138 pp.

Slamka, F., 2008: Pyraloidea of Europe (Lepidoptera) 2. Crambinae \& Schoenobiinae. Bratislava: František Slamka, 224 pp.

Slamka, F., 2013: Pyraloidea of Europe (Lepidoptera) 3. Pyraustinae \& Spilomelinae. Bratislava: František Slamka, 357 pp.

Slamka, F. \& Plant, C.W., 2016: Mecyna balcanica sp. nov., a closely related species to Mecyna flavalis ([Denis \&Schiffermüller], 1775) and M. lutealis (Duponchel, 1833) (Pyraloidea, Crambidae, Spilomelinae). Entomologist's Record and Journal of Variation 128, 137-145.

Yang, Z. \& Landry, J.-F., Handfield, L., Zhang, Y., Solis, M., Scholtens, B., Mutanen, M., Nuss, M. \& Heвert, P., 2012: DNA barcoding and morphology reveal three cryptic species of Anania (Lepidoptera: Crambidae: Pyraustinae) in North America, all distinct from their European counterpart. Systematic Entomology 37, 686-705. 